\title{
Generation and mutational analysis of a transgenic mouse model of human SRY
}

\author{
Ella Thomson ${ }^{1,2}$, Liang Zhao ${ }^{1}$, Yen-Shan Chen ${ }^{3}$, Enya Longmuss ${ }^{1}$, Ee Ting Ng${ }^{1}$, Rajini \\ Sreenivasan ${ }^{4}$, Brittany Croft $^{4}$, Xin Song ${ }^{2}$, Andrew Sinclair ${ }^{4}$, Michael Weiss ${ }^{3}$, Emanuele \\ Pelosi $^{1,2 \dagger^{*}}$, and Peter Koopman ${ }^{1 *}$
}

1. Institute for Molecular Bioscience, The University of Queensland, Brisbane, QLD 4072, Australia

2. Centre for Clinical Research, The University of Queensland, Brisbane, QLD 4072 Australia

3. Department of Biochemistry \& Molecular Biology, Indiana University School of Medicine, Indianapolis, IN 46202, USA

4. Murdoch Children's Research Institute and Department of Paediatrics, University of Melbourne, Melbourne, VIC 3052, Australia

\footnotetext{
* Joint last authors

† Author for correspondence.p.pelosi@uq.edu.au
}

Keywords: Sry, sex determination, DSD, structure-function, mouse models, CRISPR 


\section{Abstract}

SRY is the Y-chromosomal gene that determines male sex development in humans and most other mammals. After three decades of study, we still lack a detailed understanding of which domains of the SRY protein are required to engage pathway of gene activity leading to testis development. Some insight has been gained from the study of genetic variations underlying differences/disorders of sex determination (DSD), but the lack of a system of experimentally generating SRY mutations and studying their consequences in vivo has limited progress in the field. To address this issue, we generated a mouse model carrying a human $S R Y$ transgene able to drive male sex determination in XX mice. Using CRISPRCas9 gene editing, we generated novel genetic modifications in each of SRYs three domains (N-terminal, HMG box, and C-terminal) and performed detailed analysis of their molecular and cellular effects on embryonic testis development. Our results provide new functional insights unique to human $S R Y$ and the causes of DSD, and present a versatile and powerful system in which to demonstrate causality of $S R Y$ variations in DSD, to functionally study the $S R Y$ variation database, and to characterize new pathogenic $S R Y$ variations found in DSD. 


\section{Introduction}

Development of the testis in males is controlled in most eutherian mammals, including humans, by the Y-chromosome gene SRY (Koopman et al., 1991). Expressed within the somatic supporting cells of the bipotential gonad, the SRY protein activates expression of SOX9 through binding to enhancers including TESCO, eSR-A/Enh13 and eALDI (Albrecht and Eicher, 2001, Gonen et al., 2017, Croft et al., 2018). SOX9 subsequently upregulates the testis-specific developmental pathway while suppressing pro-ovarian gene expression. In the absence of $S R Y, S O X 9$ is not activated within these cells, and reciprocal ovarian-specific pathways supervene.

Despite its critical role in human evolution and biology, our understanding of the biochemical roles of SRY, and of what parts of the protein are required to carry out those roles, remains limited. While these issues have been addressed in some detail in mice (Zhao et al., 2014a), the low level of sequence conservation between human and mouse SRY, and the markedly different topographies of the two proteins (Figure 1A) renders studies in mice of limited value in understanding the structure-function relationship in human SRY.

Much of what is known about human SRY function, and the corresponding functional domains, has come from study of pathogenic variants found in human differences/disorders of sex development (DSD). Variants of SRY are the most common cause of $46, X Y$ DSD, usually manifested as partial (PGD) or complete gonadal dysgenesis (CGD) (McCannCrosby et al., 2014). The majority of $S R Y$ variants associated with $46, X Y$ DSD are found within the HMG box, which encodes the DNA-binding domain (Supplementary Table 1). Very few pathogenic variants have been described within the N-terminal domain (NTD), including truncations leading to a loss of the HMG box (Brown et al., 1998, Veitia et al., 1997, Scherer et al., 1998, Xue et al., 2019); such variants are uninformative regarding whether the $\mathrm{N}$ - 
terminal domain is required for any specific SRY functions, or what those functions might be. Similarly, only six DSD-causing variants have been identified in the C-terminal domain (CTD) (Shahid et al., 2004, Sánchez-Moreno et al., 2009, Baldazzi et al., 2003, Shahid et al., 2005, Tajima et al., 1994, Özen et al., 2017). Because the CTD has been implicated in transcriptional trans-activation (Dubin and Ostrer, 1994), it is assumed that these variants interfere with this function of the SRY protein. It remains unknown whether the NTD and/or CTD play any roles in protein stabilisation, partner protein binding, target specificity or other biochemical mechanisms.

Due to the lack of an appropriate in vivo system to test clinical impact of variants in $S R Y$, at present in vitro and cell-based experiments have provided the only way to assess SRY activity. However intriguing, such experiments do not directly test the capacity of an SRY variant to activate the male developmental program in the mammalian bipotential gonad. To circumvent this limitation, we developed a transgenic mouse model harbouring the human SRY gene ( $h S R Y$ ), which can then be interrogated in vivo by creating predetermined modifications using CRISPR. In this system, the transgene triggers formation of testes in $\mathrm{XX}$ mice, with gene-expression patterns reflecting those of typical $X Y$ testes. We showed that specific modifications to the $\mathrm{N}$ - and C-terminal and HMG domains of the $h S R Y$ transgene resulted in complete or partial loss of SRY function. We demonstrate the utility of this strategy as a genetic tool for determining SRY structure-function relationships pertinent to human sex development and developmental difference. 


\section{Results}

\section{Generation of a transgenic human SRY mouse model}

We utilised the Gateway enhanced PiggyBac system (Zhao et al., 2014b) to generate a novel transgenic mouse model. The transgene was composed of an N-terminal 3x FLAGtagged human $S R Y$ followed by an internal ribosome entry sequence (IRES) and the gene encoding enhanced green fluorescent protein (eGFP) (Figure 1B). It uses the regulatory regions of $W t 1$ - expressed in the pre-Sertoli cells of the bipotential gonad (Pelletier et al., 1991, Armstrong et al., 1993, Chen et al., 2017) — to drive expression of the transgene specifically to the developing urogenital ridge. This approach has been used successfully to express and study mouse Sry structure and function (Zhao et al., 2014a).

Transgenic mice were generated by pronuclear microinjection of the PB-Wt1-hSRY construct (Figure 1B). Breeding of a transgenic (Tg) XY male founder with a wild type female confirmed germline transmission. Splinkerette PCR analysis showed integration of a single copy of the $h S R Y$ transgene in an intergenic region of chromosome 8 with no known functions and no highly conserved regions (Supplementary Figure 1).

\section{$\mathrm{XX}$ transgenic mice develop as males}

Both $\mathrm{XY}$ and $\mathrm{XX}$ transgenic progeny appeared phenotypically male and indistinguishable from $X Y$ wild type littermates (Figure 1C). Examination of the internal reproductive organs revealed that XX Tg animals developed an entire male reproductive system, including testes and vasa deferentia rather than ovaries and uterus (Figure 1D). 
Although XY Tg testes appeared smaller than wild type controls, histological analysis showed that the seminiferous tubules of $X Y$ Tg testes were smaller than their wild type counterparts and had fewer sperm (Figure 2A). However, this did not affect the fertility of $X Y$ Tg males, which were successfully used as breeders for the propagation of the mouse line.

XX Tg mice were sterile, as expected owing to the lack of Y-chromosome genes necessary for spermatogenesis, and consistent with the phenotype of human 46,XX DSD. Their gonads were smaller than wild type testes; the seminiferous tubules lacked germ cells and displayed the typical architecture of streak XY gonads (Figure 2A). Immunofluorescence (IF) for the germ cell marker MVH confirmed that, in contrast to $\mathrm{XY}$ wild type and $\mathrm{XY} \mathrm{Tg}$ testes, and the follicles of $X X$ wild type ovaries, $X X$ Tg samples did not show any visible signal (Figure 2B).

\section{Human SRY is expressed by the supporting cells of the developing testis}

To evaluate expression of $h S R Y$ at $11.5 \mathrm{dpc}$ (when endogenous mouse Sry is expressed), expression of the FLAG protein was analysed by IF together with the somatic cell marker GATA4 and the germ cell marker MVH. FLAG expression was detected specifically within the somatic supporting cells of the gonad only in transgenic animals (Figure 3A). No expression of FLAG was seen within the primordial germ cells.

\section{$\mathrm{XX}$ transgenic mice show male gene expression patterns in the gonad}

When Sry is expressed in the bipotential gonad of a developing $X Y$ male, it upregulates Sox9, which in turn suppresses the ovary specific Fox/2. To investigate whether the $h S R Y$ transgene expression in fetal gonads induced gene expression similar to that of mouse Sry ( $m$ Sry), we performed IF for SOX9 and FOXL2 at $13.5 \mathrm{dpc}$, after the gonads have differentiated (Figure 3B). We also performed qRT-PCR analyses of embryonic gonads at both $11.5 \mathrm{dpc}$ (during the period of $m S R Y$ expression) and $13.5 \mathrm{dpc}$ (Figures 3C, 3D). Both 
analyses showed that the expression pattern of Sox9 and Foxl2 was similar between XX and $X Y T g$ gonads and wild type $X Y$ samples at fetal stages.

As the transgene was not driven by the endogenous mSry promoter, we determined the difference in expression between mSry and $h S R Y$. qRT-PCR showed that $h S R Y$ was expressed at higher levels than $m S r y$ (Figures 3C, 3D). Further, $h S R Y$ was still expressed in the gonad at $13.5 \mathrm{dpc}$, after $m$ Sry turns off. This extended expression likely has no functional consequence, because the ability of Sry to activate the testis developmental program is thought to depend only on its expression within a critical time window around $11.5 \mathrm{dpc}$.

\section{Proof of Principle: Deletion of the HMG box (“HMG-Del” mutation)}

To understand the effects of genetic variants that could inactivate the human SRY, we used CRISPR to edit the transgene in vivo. CRISPR components were electroporated into single cell mouse zygotes, which were then re-implanted and analysed between 13.5 and $14.5 \mathrm{dpc}$.

The HMG Box is the most conserved region of SRY across species (Whitfield et al., 1993) and where the majority of identified human variants in DSD individuals are located (Supplementary Table 1) . As proof of principle of the experimental system, we removed the entire HMG box in the XX Tg line (HMG-Del mutation) (Figure 4). Analysis of gonadal markers via both qPCR and IF showed typical expression of female factor Foxl2 and no obvious testicular phenotype as seen in the non-edited XX Tg embryos.

\section{Modification of the HMG box from AA131 to AA136 inactivates SRY function and prevents testis development (“Sml-HMG-Del-Mis" mutation)}

SRY must first enter the nucleus to regulate downstream gene expression, and the two nuclear localization signals (NLS) within the HMG box are believed to be necessary 
(Südbeck and Scherer, 1997, Poulat et al., 1995). We designed a guide RNA to create a double strand break to interrupt the RPRRK domain of the NLS at position AA131 ("SmlHMG-Del-Mis" alteration). A 9 bp deletion, followed by a 6 bp insertion altered this domain, while keeping the open reading frame intact (Figure 5). The resulting gonads appeared phenotypically female, and qRT-PCR confirmed that Foxl2 was expressed at levels of a typical wild-type XX ovary. Sox9 mRNA levels were higher in Sml-HMG-Del-Mis XX Tg compared to $\mathrm{XX}$ wild type gonads, but not as elevated as wild-type $\mathrm{XY}$ controls or non-edited XX Tg testes. However, SOX9 protein was not detected by IF analysis; the gonads instead showed high levels of FOXL2 throughout. These results demonstrated that the elimination of the NLS inactivated the ability of $h S R Y$ to trigger testis development.

\section{Deletion of the C-terminal domain from AA163 to AA165 results in ovotestis development (“C-Del” mutation)}

A well-studied pathogenic variant in $h S R Y$ found in DSD is an early termination at AA163 (Tajima et al., 1994). This variant eliminates the last 41 amino acids of the protein, leaving a CTD that is only 26 amino acid long. We targeted this position using a guide RNA to generate an indel and introduce a new stop codon (C-Del mutation). The resulting variant deleted codons at position 163-165 and altered the codon at position 166 (Figure 6). The resulting gonad appeared similar to a testis during gross examination. However, further characterization revealed an ovotesticular phenotype with high expression of both Sox9 and Foxl2 by qRT-PCR. IF analysis confirmed that SOX9 was confined to the centre, whereas FOXL2 was expressed throughout the gonad, as expected in ovotestes. These findings showed that loss or alteration of the C-terminal domain residues 163-166 reduced but did not eliminate hSRY function. 


\section{Early termination of the $\mathrm{N}$-terminal domain inactivates SRY function and prevents testis development (“N-STOP” mutation)}

Nine distinct variants of the SRYNTD have been reported in DSD, with over half of these resulting in early stop codons (Supplementary Table 1). We generated a change closely resembling the G54Fs*59 variant recently reported (Xue et al., 2019). A 1bp insertion at AA56 led to a frameshift and early termination codon at AA59, the second AA of the HMG Box (N-STOP mutation) (Figure 7). As expected, due to loss of the $h S R Y$ DNA binding domain, the resulting gonad developed into an ovary. qRT-PCR showed upregulation of Foxl2 and downregulation of Sox9 in mutant XX Tg gonads compared to non-edited XX Tg testes. IF staining confirmed FOXL2 expression throughout the ovary and no visible SOX9 protein was detected. These results confirm that changes that remove the HMG box result in complete inactivation of hSRY, leading to complete sex-reversal.

\section{$S R Y$ variants fail to fully activate SOX9 expression}

SRY binds to the SOX9 enhancers TESCO and Enh13 in mice, activating expression within the bipotential gonad (Gonen et al., 2017, Croft et al., 2018). To first quantify the binding of three of the $h S R Y$ variant forms generated here (HMG-Del, SmlHMG-Del-Mis, C-Del) in vitro DNA occupancy at the SOX9 enhancers was measured via ChIP-qPCR (Figure 8A, Supplementary Figure 2). As expected, no ChIP-qPCR signal was observed on transient transfection of an empty plasmid, or of an inactive variant of SRY (I68A, a "cantilever" variant that abolishes specific DNA binding (Weiss et al., 1997, Phillips et al., 2004). Each of the variants generated in the transgenic XX mice exhibited reduced TESCO/Enh13 enhancer occupancies (HMG-Del SRY: zero; C-Del mutation: 50\%; Sml-HMG-Del-Mis mutation: $\sim 20 \%$ relative to wild type (Figure 8 A). 
Next, activation of the TESCO enhancer, as well as the human eALDI enhancer, was assessed via luciferase assays (Croft et al., 2018) (Figure 8B). This was performed in COS7 cells with the addition of SF1 and compared WT SRY with the C-Del and Sml-HMG-Del-Mis variants. As expected, WT SRY alone did not activate either TESCO or eALDI enhancer, but with the addition of SF1 was able to drive luciferase expression fully. The C-Del variant was still able to activate both TESCO and eALDI enhancers to similar levels as WT SRY, while the Sml-HMG-Del-Mis showed $\sim 30 \%$ activity at TESCO and $\sim 50 \%$ activity at ALDI. We engineered additional SRY variants (Supplementary Figure 3). These also resulted in SRY inactivation but were less informative than those presented above.

Thirdly, we assessed the effect of SRY on expression of endogenous SOX9 gene in an optimized cell culture assay. Two cell lines were exploited for this purpose, $\mathrm{CH} 34$ (Haqq and Donahoe, 1998), derived from the rat gonadal ridge, and LNCap (Horoszewicz et al., 1983), derived from human prostate cancer cells. These lines were chosen as they both exhibit SRY-directed transcriptional activation of SOX9, unlike most other mammalian cell lines. We (Y-S.C., M.W.) have refined this assay over a number of years to provide a high level of reproducibility and a low level of variability (see Supplementary Figures 4 and 5, and Supplementary Methods for details); a critical feature is low level of transfected gene expression $\left(10^{3}-10^{4} \mathrm{SRY}\right.$ molecules per cell). The assay circumvents the need for a reporter construct and relies instead on an active chromatin structure at the endogenous target gene, as well as baseline expression of cofactors presumably required for assembly of an SRYdependent enhanceosome.

Using this assay, we found that HMG-Del SRY was devoid of activity and generated similar SOX9 mRNA levels to the empty vector (Figure 9A, blue bars). The C-Del variant showed $50 \%$ activation of SOX9, and the Sml-HMG-Mis-Del 30\% relative to wild type. In each case, reduced activation of SOX9 was associated with impaired expression of male-pathway- 
related genes downstream of SOX9, including Sox8, Ptgds and Fgf9, whereas expression of house-keeping genes (Gapdh, $\beta$-actin, Tbp and Yy1) was unaffected (Supplementary Figure 6). Fold-changes in $S O X 9$ transcription on transient transfection of the $S R Y$ constructs were similar in the two unrelated $S R Y$-responsive cell lines (Figure 9A) despite marked differences in baseline SOX9 mRNA abundances (Supplemental Figures 4 and 5).

\section{Blocking protein degradation rescues SRY activity in C-terminal but not HMG box or $\mathrm{N}$-terminal alterations}

To investigate whether the observed inactivation of $h S R Y$ was due to accelerated degradation of the altered forms of SRY, new protein translation was blocked using cycloheximide, and perdurance of the epitope-tagged protein was evaluated by western blot (Figure 9B). Both C-Del and HMG-Del showed accelerated degradation, while the SmlHMG-Del-Mis was comparable to wild type SRY.

When we applied the proteasomal inhibitor MG132 to block degradation, the perdurance of C-Del $h S R Y$ was fully restored, whereas no effect was observed in HMG-Del and Sml-HMGDel-Mis $h S R Y$ (Figure 9C). MG132 also restored the ability of the C-Del to activate Sox9 expression to wild type levels (Figure 9A). These findings suggest that proteasomal degradation was responsible for the pattern of decreased functional activity of C-Del $h S R Y$, in turn suggesting that the CTD of $h S R Y$ is not only involved in transcriptional activation (Dubin and Ostrer, 1994), but is also required for protein stability. 


\section{Discussion}

In the present study, we used CRISPR to modify $h S R Y$ in a transgenic mouse model and study the relationship between the resulting variants and SRY function. Variants in individuals with DSD have been reported in each of the three domains of SRY: NTD, HMG Box, and CTD. Whereas the majority of these variants are found in the HMG Box, several missense and frameshift changes have been identified within the flanking domains, providing genetic evidence of their importance for full SRY function. The critical role of the HMG domain in DNA binding and bending, and nuclear importation, has been demonstrated both in vivo and in vitro (Sánchez-Moreno et al., 2008, Kurtz et al., 2021). As proof of principle, we successfully removed the HMG box while keeping the transcript in frame. The HMG boxdeleted hSRY failed to bind to the sex-specific mouse Sox9 enhancers and activate Sox9 transcription, resulting in ovarian development in XX Tg mice. These experiments also confirmed that CRISPR HDR repair is achievable through electroporation without using any microinjection techniques, allowing a simplified workflow.

The SRY HMG box contains two nuclear localization signals (designated nNLS and cNLS) that are required for nuclear import of SRY (Poulat et al., 1995, Südbeck and Scherer, 1997, Forwood et al., 2001). The nNLS binds calmodulin (Sim et al., 2005) and Exportin4 (acting in nuclear import (Sim et al., 2005), whereas the cNLS binds importin-B. We mutated cNLS by replacing essential amino acids with missense variants. This resulted in inactivation of hSRY function and rescue of ovarian development. A different change causing a premature stop codon at AA132 also interrupted the cNLS and resulted in the same phenotype (Supplementary Figure 3). We expected that deletion of only one NLS would partially impair nuclear entry but retain specific DNA-binding/bending activity. Indeed, the Sml-HMG-Del-Mis hSRY was found in both cell lines to exhibit $~ 20 \%$ activity (as evaluated by Sox9 enhancer occupancy and Sox9 transcriptional activation; Figures 8 and 9), and this reduction in functionality could not be rescued by proteasome inhibition. We propose that this was due to 
the reduced ability of the protein to enter the nucleus, rather than its lack of DNA-binding activity. Consistent with this hypothesis, in vitro analyses of a variant SRY HMG box containing a clinical mutation in the cNLS (R133W) showed DNA-binding affinity equivalent to wild type (Harley et al., 2003, Li et al., 2001). The in vitro inactivity of HMG-Del $h S R Y$ and reduced activity of Sml-HMG-Del-Mis $h S R Y$ at equivalent levels of protein expression (Figure 9) are likely due to qualitative effects, i.e., loss of specific DNA binding in the former and impaired nuclear entry in the latter. Our results support the critical role of the cNLS for the correct SRY nuclear shuttling and function during gonadal development.

The functional role of SRY's CTD has not been fully understood. In DSD individuals, six variants have been reported in the CTD of $S R Y$ to date (Shahid et al., 2004, SánchezMoreno et al., 2009, Baldazzi et al., 2003, Shahid et al., 2005, Tajima et al., 1994, Özen et al., 2017). Affected individuals usually display female external genitalia and streak gonads. The CTD spans from AA137 to AA204 and was shown to possess transcriptional activation activity (Dubin and Ostrer, 1994). The most distal variant associated with DSD was found at AA178 and caused an early stop codon. The individual with this variation, who identified as male, exhibited ambiguous genitalia, a single testicle, and a contralateral streak gonad (Özen et al., 2017). This report suggests that while detrimental, the mutation does not completely abolish SRY function. Rare variants C-terminal to AA178 can be found in the Gnomad database (Karczewski et al., 2020). However, these variants are not associated with impaired gonadal development, suggesting that they do not significantly affect SRY activity. These reports seem to be consistent with the CTD's transcriptional activity being located within the first $\sim 40$ amino acids of this domain.

Interruption of the C-terminal AA163-166 sequence in our mouse model resulted in the development of ovotestes, which contained both Sertoli and granulosa cells. Ovotesticular DSD is the rarest form of DSD with an incidence of less than 1/20000 (Scarpa et al., 2017). Currently, only two cases of ovotestis have been reported in non-mosaic $46, X Y$ individuals, 
bioRxiv preprint doi: https://doi.org/10.1101/2021.03.04.433906; this version posted March 4, 2021. The copyright holder for this preprint (which was not certified by peer review) is the author/funder, who has granted bioRxiv a license to display the preprint in perpetuity. It is made available under aCC-BY-NC 4.0 International license.

and both mutations occurred at position AA60 in the HMG box (Berta et al., 1990, Hiort et al., 1995). In vitro analyses of these mutations showed partial activation of Sox9, indicating that SRY maintained some DNA binding activity (Phillips et al., 2011). Similarly, our C-Del $h S R Y$ retained $50 \%$ activity compared to wild type SRY, and its function was fully recovered by proteasome inhibition. Therefore, we hypothesize that the sequence around AA163-166 is important for protein stability. The C-Del mutation could also affect the partner binding activity of SRY. SRY is thought to bind the KRAB-O protein, thus recruiting KAP1 to repress transcription of pro-ovarian genes (Oh et al., 2005, Peng et al., 2009). This interaction has been mapped to the region around AA139 to AA162 of SRY, one amino acid before our CDel alteration (Oh et al., 2005). It is possible that this variant may disrupt the interaction between SRY and KRAB-O, consistent with the inability to repress expression of the ovarian gene Fox/2. Our results demonstrate that truncation or internal deletion of the CTD are associated with accelerated protein turnover. However, the C-Del mutation did not disrupt the transcriptional activation capacity of the CTD, which is unlikely to localize within positions 163-166. How the CTD protects SRY from proteasomal degradation is not well understood. It would be of future interest to investigate the critical boundary between stable and unstable CTD deletions, and whether the stabilizing effect of the native CTD is intrinsic to its length or instead mediated by specific binding to a partner protein. As previously mentioned, the mouse Sry lacks an homologous CTD but instead contains a large glutamine-rich repeat, which also protects the protein from proteasomal degradation (Zhao et al., 2014a). Analogous protection of human and mouse Sry by divergent CTDs likely reflects distinct molecular mechanisms.

Similar to the CTD, variants within the NTD of SRY are less common than those within the HMG box. Most N-terminal variants lead to early termination upstream of the HMG box, and are therefore uninformative regarding NTD function. Using CRISPR, we introduced an early termination codon at AA59, predictably showing loss of SRY's ability to direct male sex 
bioRxiv preprint doi: https://doi.org/10.1101/2021.03.04.433906; this version posted March 4, 2021. The copyright holder for this preprint (which was not certified by peer review) is the author/funder, who has granted bioRxiv a license to display the preprint in perpetuity. It is made available under aCC-BY-NC 4.0 International license.

determination and a lack of Sox9 activation. Further work will be required to generate more specific and informative NTD variants for study.

\section{Conclusions}

CRISPR technology has dramatically improved our ability to study human disorders using animal models. We have described a new mouse model system that combines zygote electroporation, CRISPR genome-editing and specific in vitro assays. In the future, this model can be used to investigate the molecular roles of SRY in initiating testicular differentiation, including studies of DSD variants and general structure-function relationships. 


\section{Methods}

\section{Generation of hSRY transgenic mice}

The Wt-hSRY transgenic mouse was generated using the methods outlined in(Zhao et al., 2014b). Briefly, the 3FLAG-hSRY-GFP was cloned into pENTR1-A, and a LR Clonase reaction was performed to introduce the 3FLAG-hSRY-GFP into the PB-Wt1-Dest vector containing the gateway enhanced piggyBAC vector with $\mathrm{Wt} 1$ regulatory regions. All animal procedures were approved by the University of Queensland Animal Ethics Committee.

The PB-Wt1-3F-hSRY-GFP and hyPBase mRNA were diluted in water for embryo transfer, 2ng/uL and 2.5ng/uL respectively and micro injected into the pronucleus of B6CBAF $1 / \mathrm{J}$ zygotes. After microinjection, zygotes grown to the 2-cell stage overnight and transferred into pseudo pregnant foster CD1 mice. From 3 microinjection sessions 60 founder pups were born, of which 5 contained the transgene ( $3 X X$ and $2 X Y$ ). Breeding between the founder $X Y$ tg and wild type females confirmed germline transmission, and the line was back crossed onto a C57BL6 background.

\section{Splinkerette PCR}

After genomic DNA extraction, splinkerette PCR was performed following the protocol outlined in (Li et al., 2010) Sanger sequencing of products was performed and aligned to regions of the mouse genome using BLAT (Kent, 2002).

\section{Genotyping}

Standard genotyping was performed by DNA extraction with QuickExtract buffer (Lucigen), after ear clipping (pups) or tail clipping (embryo). Sextyping and Tg PCR primers were used to genotype each sample. Sanger sequencing was performed on samples after genotyping with Phusion Polymerase (NEB) and PCR Purification Kit (QIAGEN). Primer sequences listed in Supplementary Table 2. 


\section{Postnatal Reproductive Organ Analysis}

Mice of each genotype (XX WT, XX Tg, XY WT, XX Tg) were culled at 6 weeks of age and their reproductive organs dissected for analysis. Ovaries and testes with epididymides were paraffin embedded and stained using the protocols outlined below.

\section{Haemotoxylin and Eosin Staining}

Paraffin embedded postnatal reproductive organs were sectioned at 7uM (Leica HistoCore Multicut Microtome). A Leica HistoCore Pearl tissue processor was used for staining, using standard haemotoxylin and eosin protocols. Slides were mounted with MountQuick (Daido Sangyo) and imaged on an Olympus BX51 Microscope with Olympus DP70 CCD camera.

\section{$\underline{\text { CRISPR Electroporation }}$}

To generate zygotes for electroporation, 3-week-old C57BL6 females were superovulated with subcutaneous injection of PMSG (5.8 IU) and HCG(7.5IU) 46 hours apart. After HCG injection, females were mated overnight with XY Tg males, and checked for presence of a copulation plug the next morning. Females were culled and oviducts collected and placed in pre-warmed M2 for zygote collection with the addition of hyaluronidase to remove cumulus cells. Zygotes washed $3 x$ in pre-warmed and $\mathrm{CO} 2$ equilibrated $\mathrm{KSOM}$ and kept at $37^{\circ} \mathrm{C}, 5 \%$ CO2.

CRISPR guide RNA and tracRNA must first be ligated to form the duplex cr:tracRNA. The crRNA (IDT) and tracRNA (IDT) were diluted to 200uM in Duplex Buffer (IDT) and mixed at an equimolar concentration to $95^{\circ} \mathrm{C}$ for $5 \mathrm{~min}$ and allowed to cool to RT. This was added to Opti-MEM to a final concentration of $6 \mu \mathrm{M}$, and $1 \mu \mathrm{L}$ of $61 \mu \mathrm{M}$ Cas9 nuclease (IDT) is added for a final concentration of $1.2 \mu \mathrm{M}$. If a HDR template was to be added, this was diluted to 
200uM and a final concentration of $20 \mu \mathrm{M}$. CRISPR mix was incubated at room temperature for 15-20 min prior to electroporation.

Electroporation was performed using the NEPA21 Electroporator System (NEPAGENE). 5uL of CRISPR mix was added to the chamber of the electrode, and up to 30 zygotes washed in pre-warmed Opti-MEM were added to the mix. The impedance was measured, and liquid was added or removed to ensure this was between 0.18 and 0.21 ohms. The poring pulse (40V, $3.5 \mathrm{~ms}, 50 \mathrm{~ms}$ interval, $4 \mathrm{x})$, and the transfer pulse $(5 \mathrm{~V}, 50 \mathrm{~ms}, 50 \mathrm{~ms}$ interval, $5 \mathrm{x})$ was administered to the zygotes, and removed immediately after. Zygotes washed 3 times in $\mathrm{KSOM}$, before overnight incubation at $37^{\circ} \mathrm{C}, 5 \% \mathrm{CO} 2$. Embryo transfer into pseudo pregnant CD1 foster mothers was performed for 2-cell embryos the next day. Transient embryo retrieval was then performed at 13.5 - or 14.5 days gestation.

\section{$\underline{\text { Immunostaining }}$}

Embryos were fixed overnight in 4\% PFA, washed with PBS, dehydrated in EtOH series and embedded in paraffin for sectioning. Sections were taken at 7uM (Leica HistoCore Multicut). For fluorescent immunostaining, slides were dewaxed in xylene and rehydrated with EtOH series $\left(100 \%, 90 \%, 80 \%, 70 \%, 50 \%, \mathrm{H}_{2} \mathrm{O}\right)$ using an autostainer (Leica HistoCore Autostainer $\mathrm{XL}$ ). Antigen retrieval was performed with high $\mathrm{pH}$ Tris-based Antigen unmasking solution (Vector Labs), then washed $\left(\mathrm{H}_{2} \mathrm{O}\right.$, PBTX) and blocked with blocking solution for 4 hours before primary antibody was added and left overnight at $4^{\circ} \mathrm{C}$. Primary antibody washed off with PBTX washed, reblocked with blocking solution for 1 hour, and secondary antibody kept on for 4 hours in the dark. Slides washed with PBTX and PBS and mounted with Prolong Gold with DAPI. Confocal imaging performed with Zeiss LSM 710 Microscope and edited with FIJI software.

Primary antibodies used - Rabbit anti-SOX9 (AB5535, Millipore, 1/800), Goat anti-FOXL2 (NovusBio NOVNB1001277, 1/100), Rabbit anti-MVH (ab13840, Abcam, 1/1000), Mouse 
anti-FLAG (Sigma F3165). Secondary antibodies used - Donkey Anti-Rabbit-568 (a10042, Invitrogen), Donkey Anti-Goat-488 (A11055, Invitrogen), Goat Anti-Mouse-568 (A11003, Invitrogen).

\section{$\underline{\text { qRT-PCR }}$}

During embryo dissection, one gonad with mesenephros was removed and kept in RNAlater (Qiagen) at $-20^{\circ} \mathrm{C}$ until RNA extraction. RNA extraction performed using RNEasy Micro Kit (QIAGEN), and RNA converted to cDNA with High Capacity RNA to cDNA Kit (Applied Biosystems). Triplicate SYBR qRT-PCR assays were performed on the QuantStudio 7 machine (Applied Biosystems), and relative level of expression was calculated after normalisation to Tbp. Primers used are listed in Supplemental Table 2. Statistical analyses performed in Prism.

\section{$\underline{\text { Mammalian expression plasmids }}$}

Plasmids expressing full-length SRY and variants were constructed by PCR and verified by DNA sequencing. Following the initiator Met, the cloning site encoded a hemagglutinin $(\mathrm{HA})$ tag in triplicate to enable Western blotting (WB) and chromatin immunoprecipitation (ChIP).

\section{$\underline{\text { Cell culture }}$}

Rodent CH34 cells (Haqq and Donahoe, 1998, Chen et al., 2013) were cultured in Dulbecco's modified Eagle's medium (DMEM) containing 5\% fetal bovine serum (FBS) at $37^{\circ} \mathrm{C}$ in $5 \% \mathrm{CO}_{2}$. LNCaP cells (ATCC® CRL-1740 ${ }^{\mathrm{TM}}$ ) were obtained from ATCC and cultured in DMEM medium containing $10 \%$ FBS in $5 \%$ CO2.

\section{$\underline{\text { Transient transfections }}$}

Transfections were performed using Lipofectamine 3000 as described by the vendor (Invitrogen). After 8 hours in Opti-MEM medium, cells were recovered using fresh culture medium with FBS: Dulbecco's Modified Eagle Medium (DMEM) for $\mathrm{CH} 34$ cells and 
Roswell Park Memorial Institute (RPMI) medium for LNCaP cells. Transfection efficiencies were determined by ratio of green-fluorescent protein (GFP) positive cells to untransfected cells following co-transfection with pCMX-SRY and PCMX-GFP in equal amounts (Chen et al., 2013). Subcellular localization was visualized by immunostaining 24-h post transfection following treatment with $0.01 \%$ trypsin (Invitrogen) and plating on 12-mm cover slips. To assess transfection efficiency, cells were visualized via fluorescence microscopy for qualitative assessment of protein expression, morphology, and viability. SRY expression was monitored by WB via its triplicate HA tag.

\section{$\underline{\text { Chromatin immunoprecipitation }}$}

Cells were transfected with epitope-tagged WT or variant SRY. SRY-expressing cells were cross-linked in wells by formaldehyde, collected, and lysed after quenching the cross-linking reaction. Lysates were sonicated to generate fragments and immunoprecipitated with antiHA antiserum (Sigma) containing a Protein A slurry (Cell Signaling). A non-specific antiserum (control IgG; Santa Cruz) served as non-specific control. PCR and qPCR protocols were as described (Racca et al., 2016). Quantification of immunoprecipitated enhancer was performed by qPCR (Racca et al., 2016) and representative gel images were collected by Gel Doc (Bio-Rad).

\section{$\underline{\text { Cycloheximide assay and western blotting }}$}

24-h post transient transfection, cells were split evenly into 6-well plates and treated with cycloheximide to a final concentration of $20 \mu \mathrm{g} / \mathrm{ml}$ in DMEM for the indicated times; cells were then lysed by RIPA buffer (Cell Signaling Technology). Protein concentrations were measured by BSA assay (Thermo); cell lysates were subjected to 4-20\% SDS-PAGE and WB using anti-HA antiserum (Sigma-Aldrich) at a dilution ratio of 1:5000; $\alpha$-tubulin antiserum provided a loading control. For phosphorylation analysis, HA-tagged SRY variants were immunoprecipitated with rabbit polyclonal anti-phosphoserine antiserum (Abcam). WB following 4-20\% sodium dodecyl sulfate-polyacrylamide gel electrophoresis (SDS-PAGE) 
employed HRP-conjugated anti-HA antibody (Roche). Quantification was performed by Image $\mathrm{J}$ software.

\section{$\underline{\text { Transcriptional activation assay }}$}

In the transient transfections the expression plasmid encoding HA-tagged WT SRY or an HA-tagged variant SRY was diluted 1:50 with the parent empty plasmid to reduce protein expression to the physiological range $\left(\mathrm{ca} .10^{3}-10^{4}\right.$ protein molecules/cell (Chen et al., 2013)); similar expression levels were verified by anti-HA Western blot. Following transient transfection, cellular RNA was extracted and converted to cDNA by using vendor's protocol (Bio-Rad). SRY-mediated transcriptional activation of SOX9/Sox9 was measured in triplicate by qPCR as described (Chen et al., 2013). Primer sequences for all of the tested genes were applied as described (Chen et al., 2013, Racca et al., 2016). Tbp, encoding the specific 5'-TATAADNA-binding subunit of TFIID, was used as an internal control; experiments included three technical replicates of each of three biological replicates. For further detail see Supplementary Methods.

\section{Luciferase Assays}

To assess mutant or wild-type SRY activity, in vitro luciferase assays were performed as described in Croft et al. (2018). Briefly, COS7 cells were seeded in a 96-well plate for 2-4 hours in DMEM with $10 \%$ foetal bovine serum at $37^{\circ} \mathrm{C}$ with $5 \% \mathrm{CO}_{2}$. At $80-90 \%$ confluency, $75 \mathrm{ng}$ of the enhancer-luciferase reporter constructs pGL4-eALDI, pGL4-TESCO or empty pGL4.10 (Promega;(Croft et al., 2018)) were individually transfected into the cells in each well in duplicates, together with $100 \mathrm{ng}$ each of the following transcription factors in pCDNA3.1-based expression constructs: SF-1, wild-type/mutant SRY or SF-1 + wildtype/mutant SRY. The pRL-TK plasmid (Promega; $15 \mathrm{ng}$ ) expressing Renilla luciferase was included as an internal control. The cells were transfected using Lipofectamine 2000 (Thermo Fisher Scientific) for 24 hours. Cells were then lysed and firefly and Renilla luciferase activities assayed using the Dual Luciferase Reporter Assay System (Promega). 
bioRxiv preprint doi: https://doi.org/10.1101/2021.03.04.433906; this version posted March 4, 2021. The copyright holder for this preprint (which was not certified by peer review) is the author/funder, who has granted bioRxiv a license to display the preprint in perpetuity. It is made available under aCC-BY-NC 4.0 International license.

Four independent assays were performed, and firefly luciferase activity was normalised against that of Renilla luciferase. Fold change was calculated by normalising luciferase activity against the average of the empty vector pCDNA3.1. Data was represented as mean fold change of the four biological replicates with standard error of the mean (SEM).

Statistical significance was assessed by performing two-tailed Student's paired t-tests using Graphpad Prism V7. 


\section{Acknowledgements}

We thank Johnny Huang for performing microinjections and the UQ Transgenic Animal Service of Queensland (TASQ) for performing embryo transfer. We thank P.K. Donahoe (Massachusetts General Hospital, Boston, MA) for kindly providing the $\mathrm{CH} 34$ cell line. This work was supported by research grants from the National Health and Medical Research Council of Australia, and the Distinguished Professor endowment at Indiana University (MAW).

Abbreviations. ALDI, Alternate Long-Distance Initiator; ChIP, chromatin immunoprecipitation; CTD, C-terminal domain; DSD, differences (or disorders) in sexual differentiation; FBS, fetal blood serum; GFP, green fluorescent protein; HA, haemagglutinin; HMG, high mobility group; HRP, horse radish peroxidase; hSRY, human SRY; mSRY, mouse Sry; NTD, Nterminal domain; PCR, polymerase chain reaction; qRT-PCR, quantitative real-time reversetranscriptase PCR; SDS-PAGE, sodium dodecyl sulfate-polyacrylamide gel electrophoresis; SRY/Sry, sex-determining region of the Y chromosome; TESCO, testis-specific enhancer core element; TF, transcription factor; Tg, transgenic; WB, western blot. Amino acids are designated by standard one- or three-letter codes. Names of genes (or acronyms) are italicized. 
A.

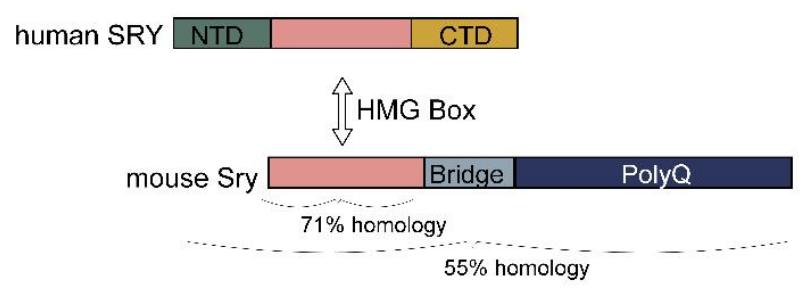

B.

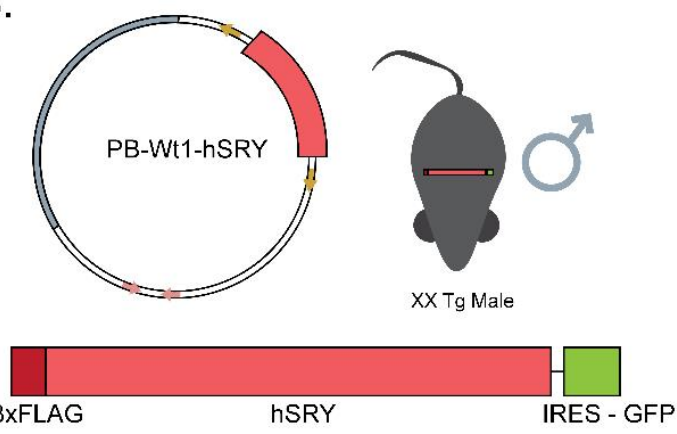

C.

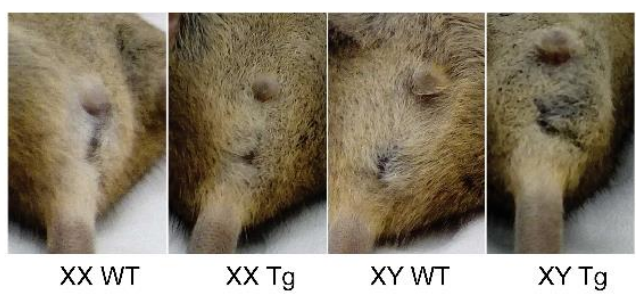

D.

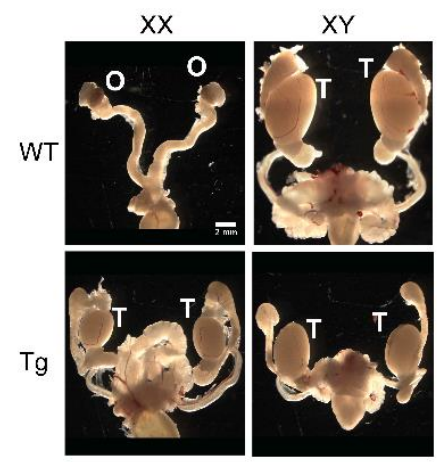

Figure 1: Generation of the human $S R Y$ sex reversed mouse line

A. The Sry gene in human and mouse is highly divergent. Both contain the HMG box, encoding the DNA binding domain (pink) which is $71 \%$ homologous between the species. Human $S R Y$ has an N-terminal (green) and C-terminal domain (yellow) which are not seen in the mouse. B. The PB-Wt1-hSRY construct was generated with a 3xFLAG-hSRY gene, followed by a GFP reporter. This was inserted into the mouse genome, resulting in XX Tg mice appearing as male. XY Tg mice are used to breed for propagation of the line. $\mathbf{C}$. The external reproductive organs of WT and Tg 6-week-old WT and Tg mice. XX WT mice show the urethral and vaginal orifice, while $X X \mathrm{Tg}$ and $X Y \mathrm{Tg}$ show a penis and scrotal sac consistent with XY WT anatomy. D. The internal reproductive organs of WT and Tg 6-weekold $X Y$ and $X X$ mice. WT $X X$ mice develop ovaries, while $X X$ Tg and $X Y$ Tg mice show testis development. Both XX and XY Tg have smaller testis than the XY WT control. T, testis; O, ovary. Scale bar, $2 \mathrm{~mm}$. 
bioRxiv preprint doi: https://doi.org/10.1101/2021.03.04.433906: this version posted March 4, 2021. The copyright holder for this preprint (which was not certified by peer review) is the author/funder, who has granted bioRxiv a license to display the preprint in perpetuity. It is made available under aCC-BY-NC 4.0 International license.

A.

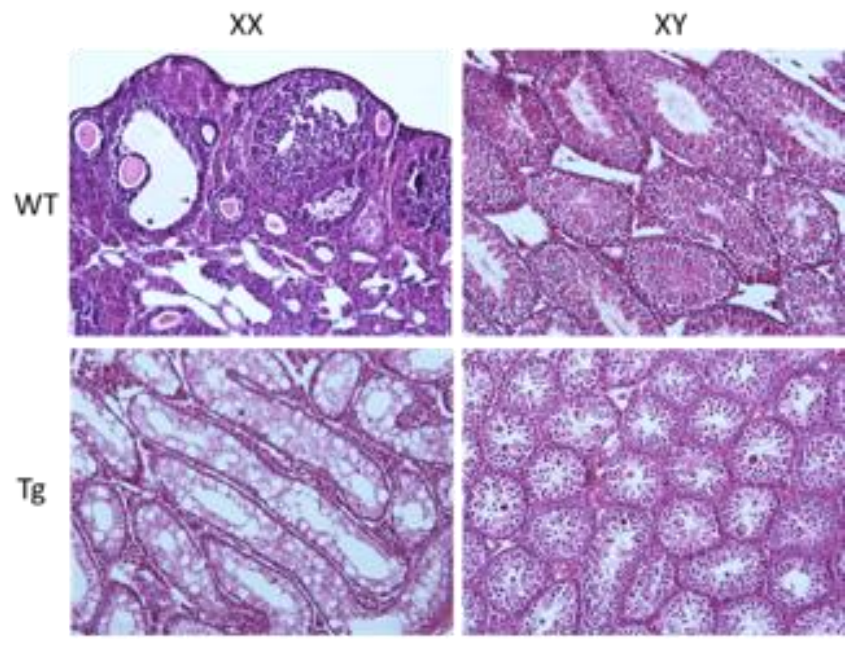

B.

$\mathrm{XX}$

$\mathrm{XY}$

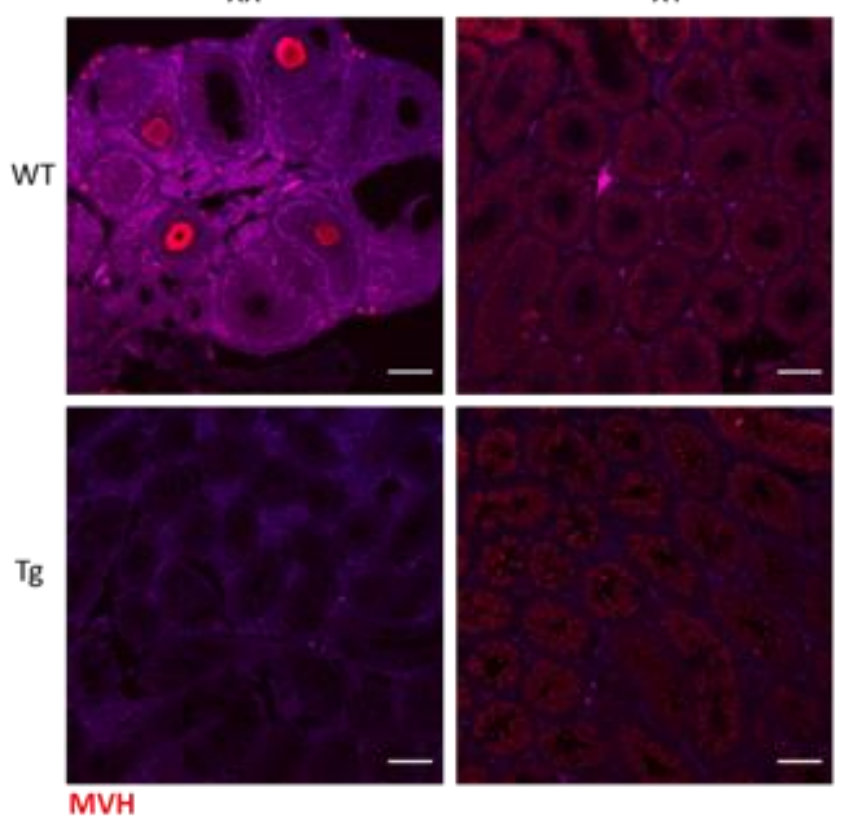

Figure 2: Postnatal analysis of the $h S R Y$ mouse line

A. Morphology of 6-week postnatal gonads was assessed via $\mathrm{H}$ \& $E$ staining. $X X$ and $X Y$ samples showed typical ovarian and testicular morphology. XX Tg samples appear testicular however no sperm are visible, and dysgenesis of the testis cords is apparent. $\mathrm{XY} \mathrm{Tg}$ samples show a typical male testicular morphology. B. MVH staining of the postnatal sections identifies germ cells within the tissue. XX WT samples show staining within the ovarian follicles, and XY WT and XY Tg samples show MVH expression within testis cords. No staining is evident within the XX Tg samples. Scale bar, $100 \mu \mathrm{m}$. 
A.

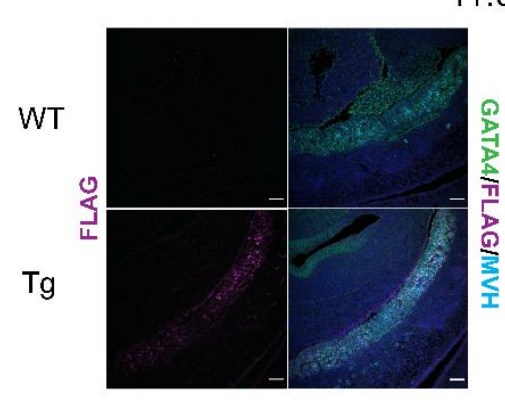

$\mathrm{XX}$
$11.5 \mathrm{dpc}$

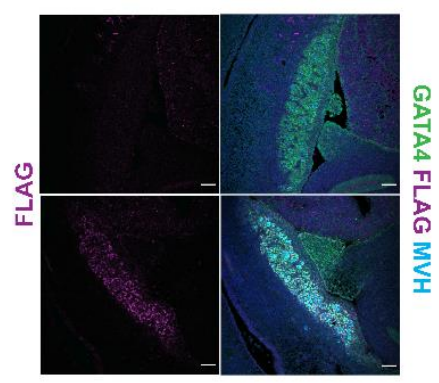

$X Y$
B.

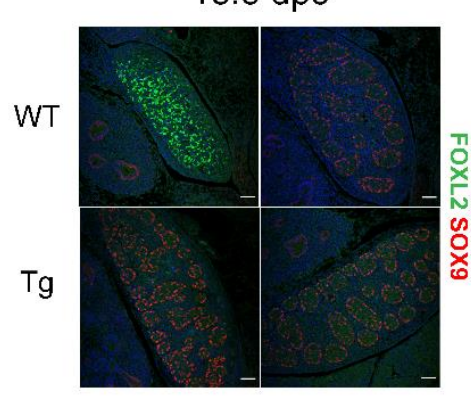

$X X$
C. $11.5 \mathrm{dpc}$

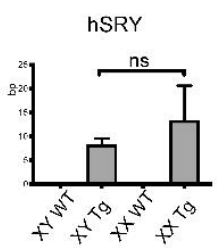

SoX9

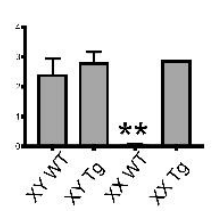

mSRY
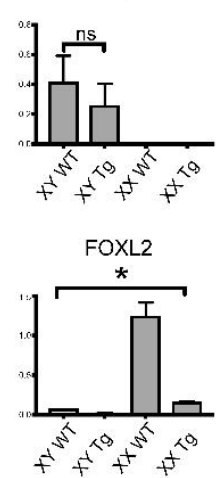

D.
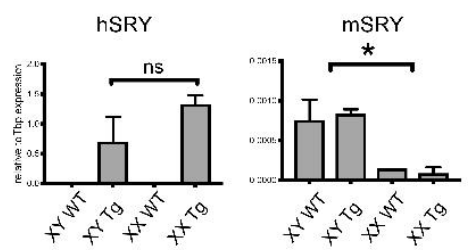

mSRY \& hSRY

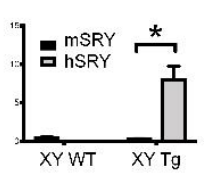

Sox9

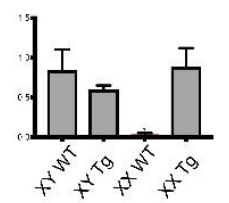

FOXL2

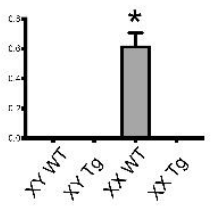

Figure 3: Gene Expression Analysis of $h S R Y$ mouse line

A. Expression of FLAG, GATA4 and MVH was assessed via IHC in 11.5 dpc gonads.

Expression of FLAG can be seen only in Tg samples, with no expression visible in XX WT or XY WT samples. GATA4 marks the somatic cells of the gonad, and MVH marks the germ cells. Similar levels of each are visible throughout all genotypes. Bar $=50 \mu \mathrm{m}$. B. Sertoli cell marker (SOX9) and granulosa cell marker (FOXL2) were analysed in 13.5 dpc samples. XX WT samples show extensive FOXL2 staining with no SOX9 visible. Both XX Tg and XY Tg samples show similar staining patterns XY WT with SOX9 staining throughout testis cords. Bar $=50 \mu \mathrm{m}$. C. Expression levels of $h S R Y, m S R Y$, Sox9 and FoxL2 in were measured in XY WT, XY Tg, XX WT, XX Tg gonads at 11.5 dpc. D. Expression level of same markers at $13.5 \mathrm{dpc}$. In both $11.5 \mathrm{dpc}$ and $13.5 \mathrm{dpc}$ samples, $h S R Y$ is expressed within both $\mathrm{XY}$ and $\mathrm{XX}$ Tg lines, and this is expressed at levels much higher than the endogenous mouse Sry in XY 
bioRxiv preprint doi: https://doi.org/10.1101/2021.03.04.433906; this version posted March 4, 2021. The copyright holder for this preprint (which was not certified by peer review) is the author/funder, who has granted bioRxiv a license to display the preprint in perpetuity. It is made available under aCC-BY-NC 4.0 International license.

lines. Sox9 expression with $X X$ and $X Y$ Tg lines at both timepoints is consistent with $X Y$ WT male expression. Fox/2 expression in XX WT is significantly higher than all other genotypes, however XX Tg mice at 11.5 dpc show higher levels than XY samples. 
A.

\begin{tabular}{|l|l|}
\multicolumn{2}{|c}{ fo $_{\text {NTD }}$ HMG BOX } \\
\hline NTD & CTD \\
\hline
\end{tabular}

C.

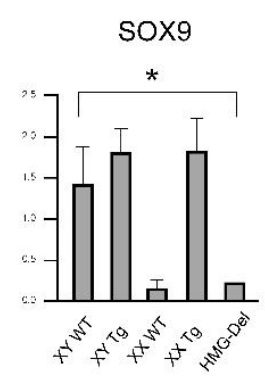

B.

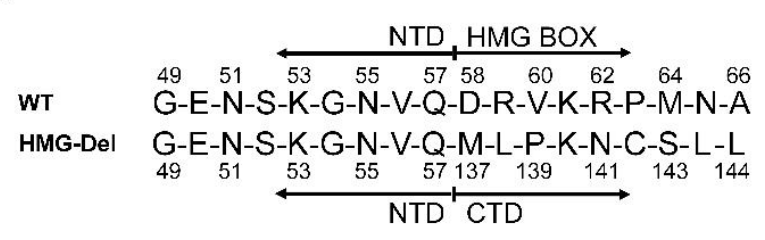

D.

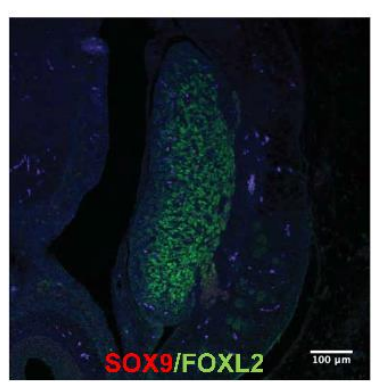

Figure 4: The HMG-Del mutation

A. Strategy to generate the HMG-Del variant via CRISPR in XX Tg mice. B. Detail of modification in the WT and mutant SRY sequences. C. SOX9 and FOXL2 levels as measured by qPCR of the embryonic gonads. ${ }^{*}=p<0.05 ;{ }^{* * *}=p<0.0001 \mathrm{D}$. IHC of the resulting gonad at $14.5 \mathrm{dpc}$, stained by SOX9 (red) and FOXL2 (green). 
A.

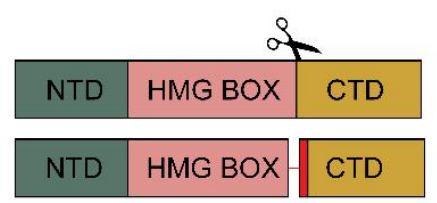

C.

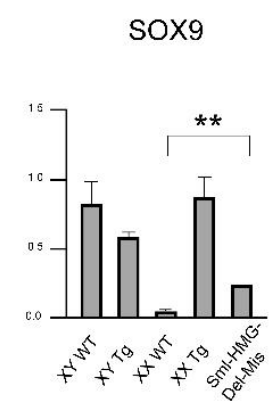

FOXL2

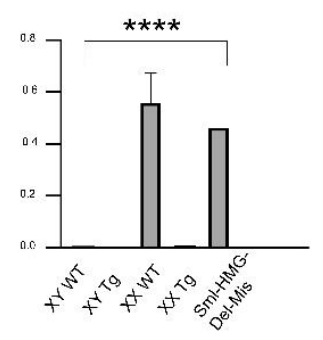

B.

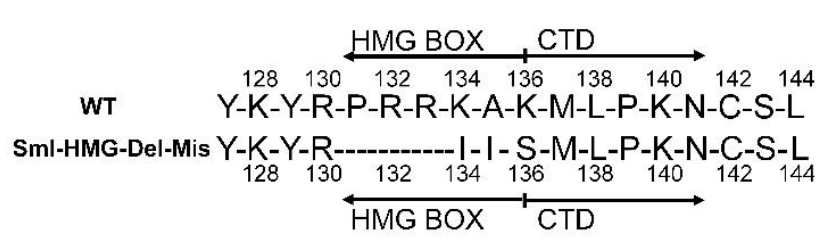

D.

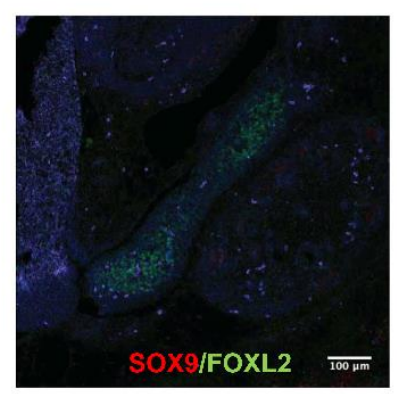

\section{Figure 5: The Sml-HMG-Del-Mis mutation}

A. Strategy to generate the Sml-HMG-Del-Mis variant via CRISPR in XX Tg mice. B. Detail of modification in the WT and mutant SRY sequences. C. SOX9 and FOXL2 levels as measured by qPCR of the embryonic gonads. ${ }^{* *}=p<0.01 ;{ }^{* * * *}=p<0.0001 \mathrm{D}$. IHC of the resulting gonad at $14.5 \mathrm{dpc}$, stained by SOX9 (red) and FOXL2 (green). 
A.

\begin{tabular}{|l|l|l|}
\multicolumn{2}{c}{ of } \\
\hline NTD & HMG BOX & CTD \\
\hline NTD & HMG BOX & \\
\hline
\end{tabular}

C.

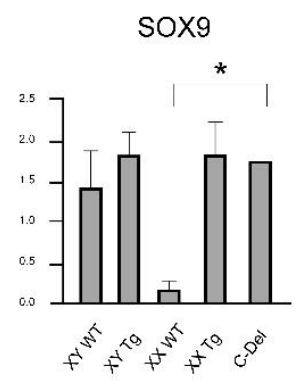

B.

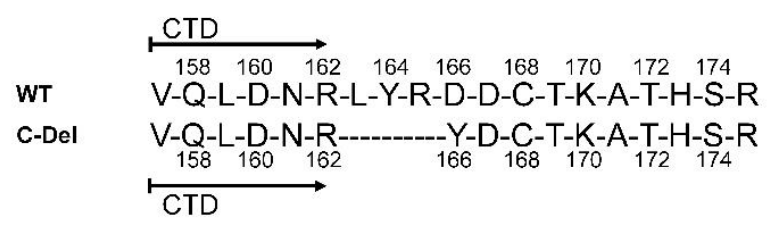

D.

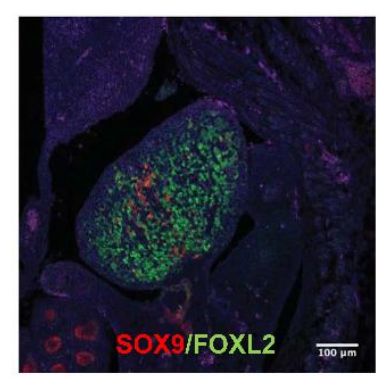

\section{Figure 6: The C-Del mutation}

A. Strategy to generate the C-Del variant via CRISPR in XX Tg mice. B. Detail of modification in the WT and mutant SRY sequences. C. SOX9 and FOXL2 levels as measured by qPCR of the embryonic gonads. ${ }^{*}=p<0.05$. D. IHC of the resulting gonad at $14.5 \mathrm{dpc}$, stained by SOX9 (red) and FOXL2 (green). 
A.

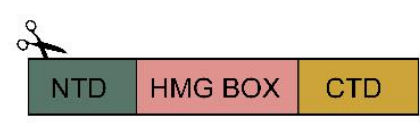

NTD

C.

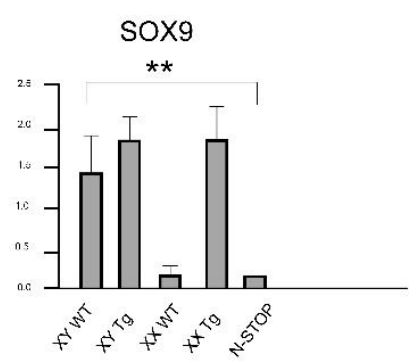

B.

WT

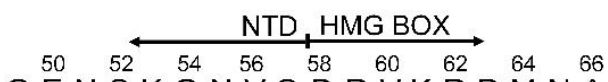

NTD-Del G-E-N-S-K-G-N-V-Q-D-R-V-K-R-P-M-N-A

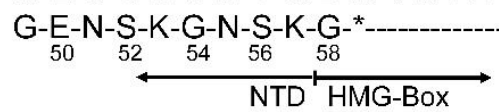

D.

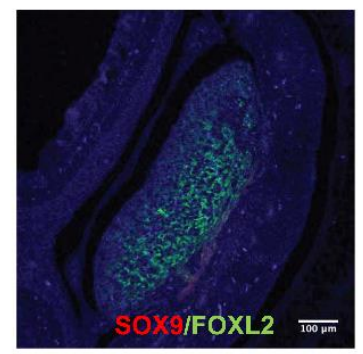

\section{Figure 7: The N-STOP mutation}

A. Strategy to generate the N-STOP variant via CRISPR in XX Tg mice. B. Detail of modification in the WT and mutant SRY sequences. C. SOX9 and FOXL2 levels as measured by qPCR of the embryonic gonads. ${ }^{* *} p<0.01 ;{ }^{* * *} p<0.0001 \mathrm{D}$. IHC of the resulting gonad at $14.5 \mathrm{dpc}$, stained by SOX9 (red) and FOXL2 (green). 
A.

B.
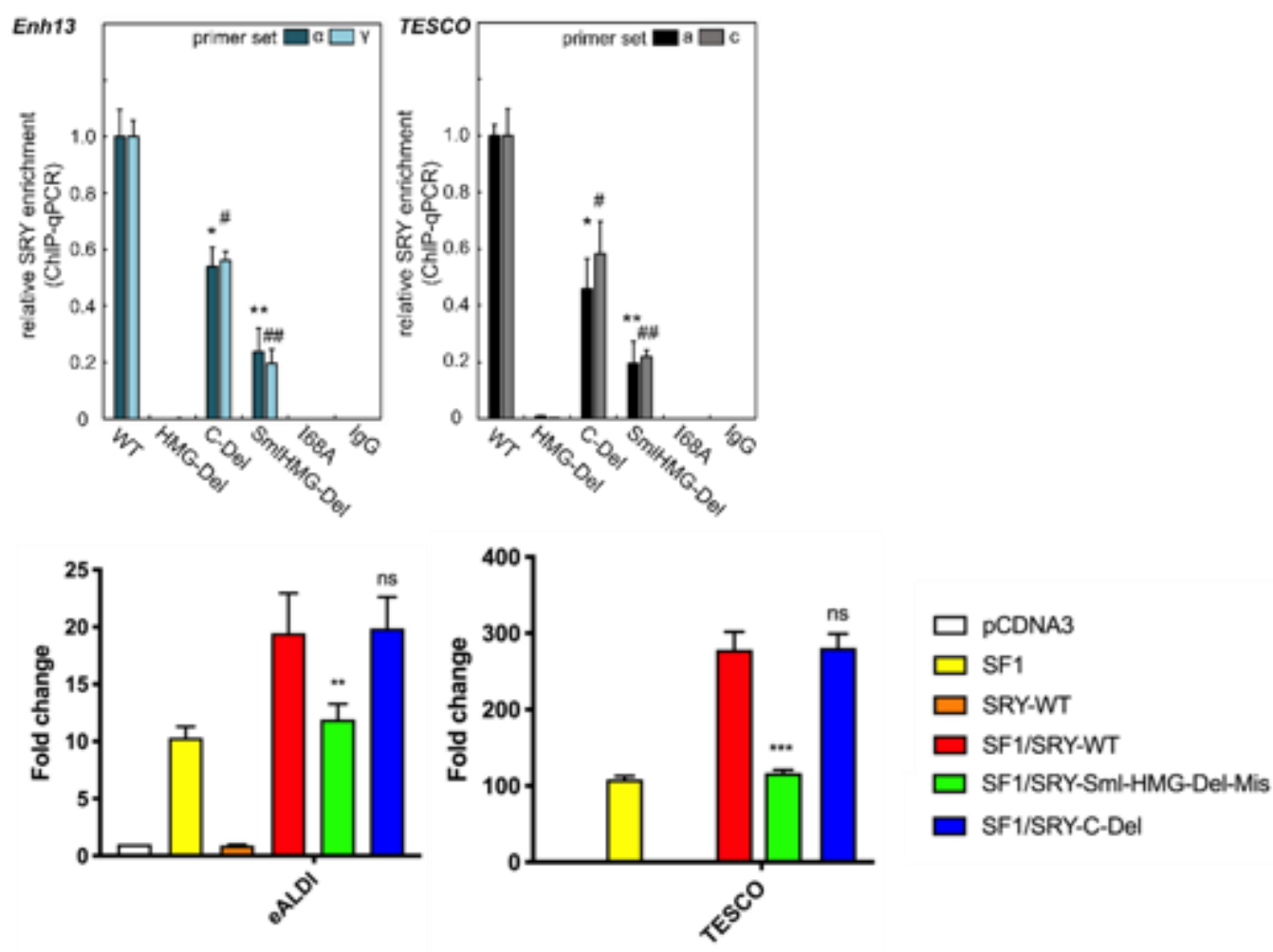

Figure 8: SRY variant activity in vitro

A. SOX9 enhancer occupancies associated with various SRY mutations. SRY-Enh13 (left) and SRY-TESCO (right) complexes were probed by ChIP assays and quantified by qPCR; results are summarized by histogram. The experiments was conducted in triplicate on three biological replicates in CH34 cells. Results were normalized relative to WT SRY (far left in each panel). Control lanes I68A and IgG indicate inactive SRY variant and non-specific control. Error bars represent standard deviation. ${ }^{*} p<0.05$, primer set $\alpha$ or $a, \# p<0.05$, primer set $\gamma$ or $\mathrm{c},{ }^{* *} \mathrm{p}<0.01$, primer set $\alpha$ or $\mathrm{a}, \# \# \mathrm{p}<0.01$, primer set $\gamma$ or $\mathrm{c}$. B. In vitro luciferase assays to assess transcriptional activation of the SOX9 eALDI and TESCO enhancers in COS7 cells by SF1 and either wild-type or mutant SRY. The data is represented as mean fold change of luciferase activity, relative to that obtained by the empty pCDNA3 vector, from four independent assays, each with two technical replicates. Error bars represent standard error of the mean (SEM). Ratio paired parametric t-tests were performed and differences in luciferase activity compared to SF1 are depicted above 
bioRxiv preprint doi: https://doi.org/10.1101/2021.03.04.433906; this version posted March 4, 2021. The copyright holder for this preprint (which was not certified by peer review) is the author/funder, who has granted bioRxiv a license to display the preprint in perpetuity. It is made available under aCC-BY-NC 4.0 International license.

corresponding bars. Differences in luciferase activity compared to SF1/SRY-WT are

depicted on lines above the bars. ${ }^{*} p<0.05,{ }^{* *} p<0.01,{ }^{* * *} p<0.001,{ }^{* * *} p<0.0001$, ns: not significant, WT: wild type. 
A.
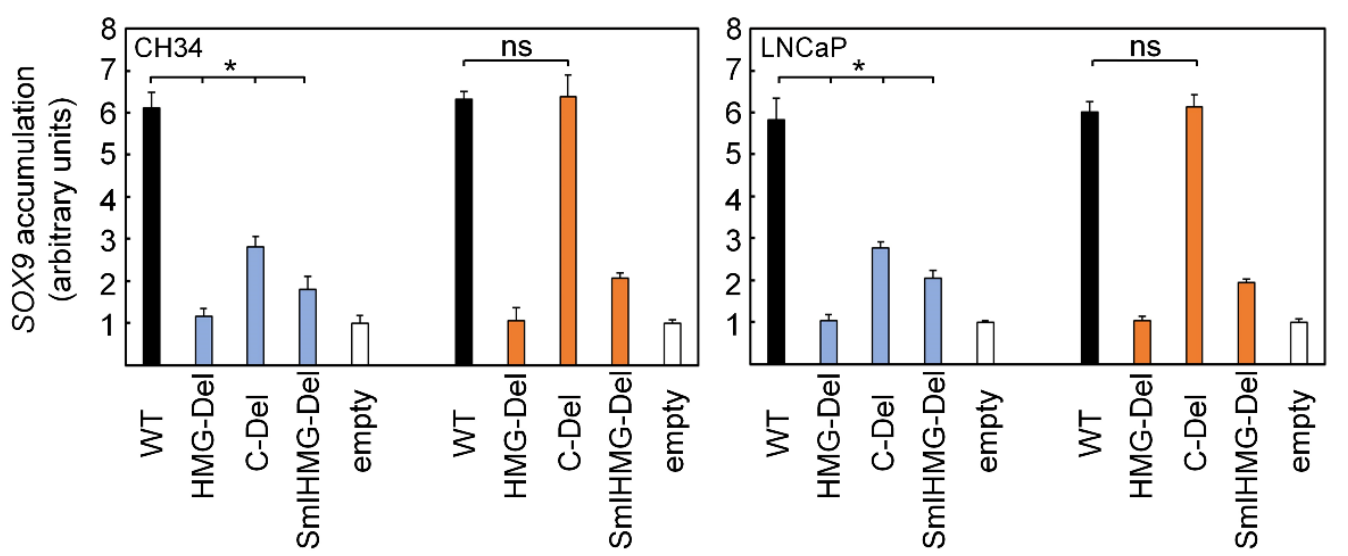

B.

C.
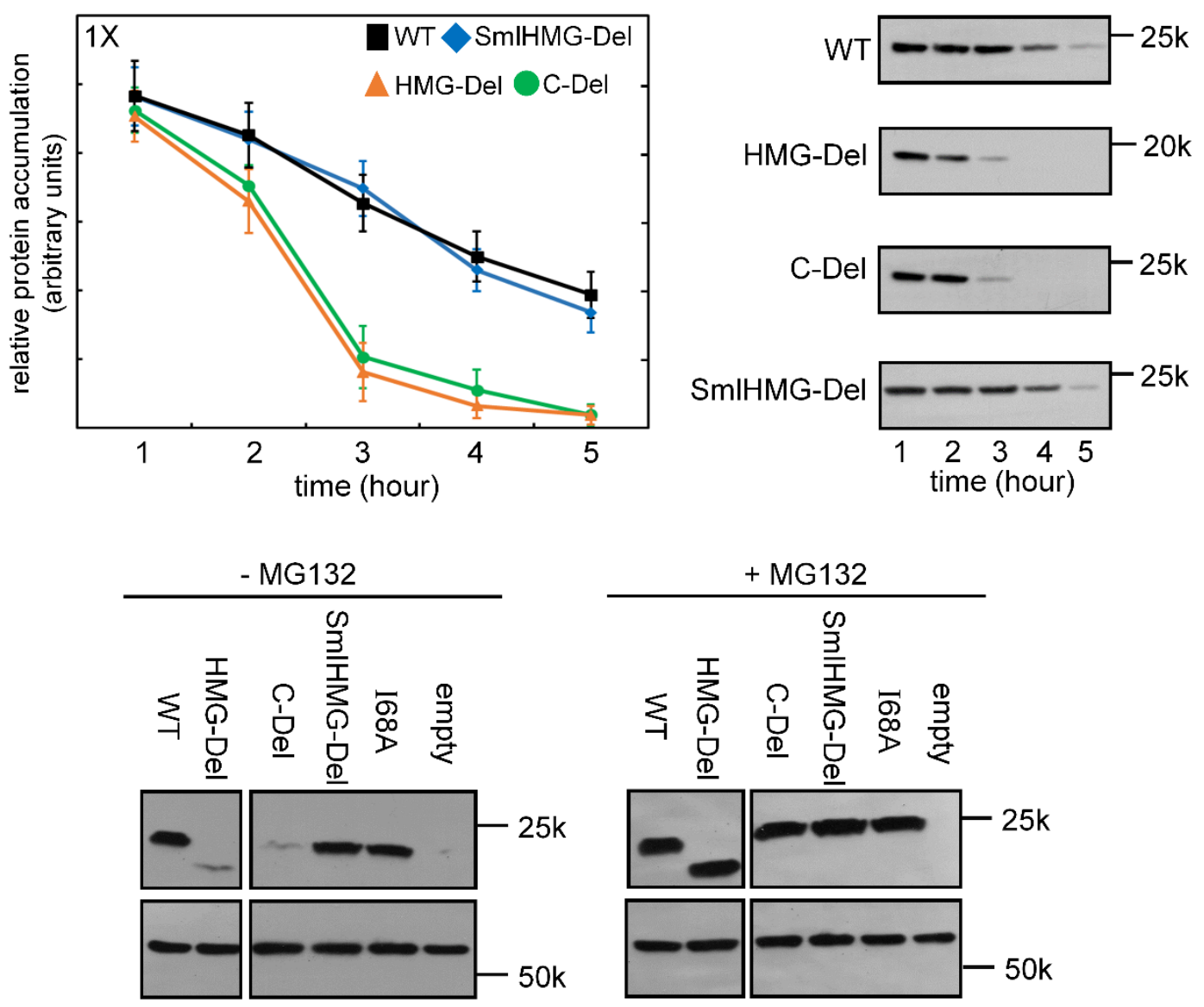

Figure 9: Proteasomal degradation of SRY variants

A. Sox9 expression after transfection of SRY variants. The normalized qPCR data were obtained in the absence (left, blue) or presence (right, orange) of MG132 in CH34 and LNCaP cells. Vertical axis provides fold-changes in abundance of SOX9 mRNA (a ratio); see 
Supplemental Figures 4 and 5 (in absence/presence of MG132) for individual terms in ratio.

The experiment was performed in triplicate on three biological replicates. B. SRY protein degradation assays in $\mathrm{CH} 34$ cell lines. The semilog plot of SRY concentration as a function of time (left) following cycloheximide arrest of new protein translation. Western blots (WBs; right) exhibited similar time courses. C. Addition of proteasome inhibitor MG132 restores SRY protein accumulation in cells to WT levels. WB employed anti-HA antiserum; loadingcontrol $\alpha$-tubulin is shown in lower box. 


\section{References}

Affara, N. A., Chalmers, I. J. \& Ferguson-Smith, M. A. 1993. Analysis of the SRY gene in 22 sex-reversed $X Y$ females identifies four new point mutations in the conserved DNA binding domain. Hum Mol Genet, 2, 785-9.

Albrecht, K. H. \& Eicher, E. M. 2001. Evidence that Sry is expressed in pre-Sertoli cells and Sertoli and granulosa cells have a common precursor. Dev Biol, 240, 92-107.

Andonova, S., Robeva, R., Sirakov, M., Mainhard, K., Tomova, A., Ledig, S., . . Savov, A. 2015. A Novel SRY Gene Mutation p.F109L in a 46,XY Female with Complete Gonadal Dysgenesis. Sex Dev, 9, 333-7.

Armstrong, J. F., Pritchard-Jones, K., Bickmore, W. A., Hastie, N. D. \& Bard, J. B. 1993. The expression of the Wilms' tumour gene, WT1, in the developing mammalian embryo. Mech Dev, 40, 85-97.

Assumpção, J. G., Benedetti, C. E., Maciel-Guerra, A. T., Guerra, G., Jr., Baptista, M. T., Scolfaro, M. R. \& De Mello, M. P. 2002. Novel mutations affecting SRY DNA-binding activity: the HMG box N65H associated with 46,XY pure gonadal dysgenesis and the familial non-HMG box R30I associated with variable phenotypes. J Mol Med (Berl), $80,782-90$.

Baldazzi, L., Nicolettic, A., Gennari, M., Barbaro, M., Pirazzoli, P., Cicognani, A. \& Cacciari, E. 2003. Two new point mutations of the SRY gene identified in two Italian $46, X Y$ females with gonadal dysgenesis. Clinical Genetics, 64, 258-260.

Bastian, C., Muller, J. B., Lortat-Jacob, S., Nihoul-Fékété, C., Bignon-Topalovic, J., Mcelreavey, K., ... Brauner, R. 2015. Genetic mutations and somatic anomalies in association with 46,XY gonadal dysgenesis. Fertil Steril, 103, 1297-304.

Battaglia, F., Plotti, F., Angelucci, M., Aloisi, A. \& Angioli, R. 2013. Novel mutation of the sexdetermining region on the $\mathrm{Y}$ chromosome in a $46, \mathrm{XY}$ female patient with monolateral dysgerminoma: a case report. J Obstet Gynaecol Res, 39, 442-5.

Battiloro, E., Angeletti, B., Tozzi, M. C., Bruni, L., Tondini, S., Vignetti, P., . . D'ambrosio, E. 1997. A novel double nucleotide substitution in the HMG box of the SRY gene associated with Swyer syndrome. Hum Genet, 100, 585-7.

Berta, P., Hawkins, J. B., Sinclair, A. H., Taylor, A., Griffiths, B. L., Goodfellow, P. N. \& Fellous, M. 1990. Genetic evidence equating SRY and the testis-determining factor. Nature, 348, 448-450.

Bilbao, J. R., Loridan, L. \& Castaño, L. 1996. A novel postzygotic nonsense mutation in SRY in familial XY gonadal dysgenesis. Hum Genet, 97, 537-9. 
Braun, A., Kammerer, S., Cleve, H., Löhrs, U., Schwarz, H. P. \& Kuhnle, U. 1993. True hermaphroditism in a 46,XY individual, caused by a postzygotic somatic point mutation in the male gonadal sex-determining locus (SRY): molecular genetics and histological findings in a sporadic case. Am J Hum Genet, 52, 578-85.

Brown, S., Yu, C. C., Lanzano, P., Heller, D., Thomas, L., Warburton, D., . . Stadtmauer, L. 1998. A De Novo Mutation (GIn2Stop) at the 5\&\#x2032; End of the SRY Gene Leads to Sex Reversal with Partial Ovarian Function. The American Journal of Human Genetics, 62, 189-192.

Cameron, F. J., Smith, M. J., Warne, G. L. \& Sinclair, A. H. 1998. Novel mutation in the SRY gene results in 46,XY gonadal dysgenesis. Hum Mutat, Suppl 1, S110-1.

Chen, L., Ding, X. P., Wei, X. \& Li, L. X. 2014. Investigation of mutations in the SRY, SOX9, and DAX1 genes in sex reversal patients from the Sichuan region of China. Genet Mol Res, 13, 1518-26.

Chen, M., Zhang, L., Cui, X., Lin, X., Li, Y., Wang, Y., . . Gao, F. 2017. Wt1 directs the lineage specification of sertoli and granulosa cells by repressing $<\mathrm{em}>\mathrm{Sf} 1</ \mathrm{em}>$ expression. Development, 144, 44-53.

Chen, Y. S., Racca, J. D., Phillips, N. B. \& Weiss, M. A. 2013. Inherited human sex reversal due to impaired nucleocytoplasmic trafficking of SRY defines a male transcriptional threshold. Proc Natl Acad Sci U S A, 110, E3567-76.

Croft, B., Ohnesorg, T., Hewitt, J., Bowles, J., Quinn, A., Tan, J., . . Sinclair, A. 2018. Human sex reversal is caused by duplication or deletion of core enhancers upstream of SOX9. Nature Communications, 9, 5319.

Cunha, J. L., Soardi, F. C., Bernardi, R. D., Oliveira, L. E., Benedetti, C. E., Guerra-Junior, G., . . De Mello, M. P. 2011. The novel p.E89K mutation in the SRY gene inhibits DNA binding and causes the 46,XY disorder of sex development. Braz J Med Biol Res, 44, 361-5.

De Sousa, S. M., Kassahn, K. S., Mcintyre, L. C., Chong, C. E., Scott, H. S. \& Torpy, D. J. 2016. Case report of whole genome sequencing in the $X Y$ female: identification of a novel SRY mutation and revision of a misdiagnosis of androgen insensitivity syndrome. BMC Endocr Disord, 16, 58.

Domenice, S., Yumie Nishi, M., Correia Billerbeck, A. E., Latronico, A. C., Aparecida Medeiros, M., Russell, A. J., . . Bilharinho Mendonca, B. 1998. A novel missense mutation $(\mathrm{S} 18 \mathrm{~N})$ in the $5^{\prime}$ non-HMG box region of the SRY gene in a patient with partial gonadal dysgenesis and his normal male relatives. Hum Genet, 102, 213-5.

Dubin, R. A. \& Ostrer, H. 1994. Sry is a transcriptional activator. Mol Endocrinol, 8, 1182-92. 
Eggers, S., Sadedin, S., Van Den Bergen, J. A., Robevska, G., Ohnesorg, T., Hewitt, J., . . . Sinclair, A. H. 2016. Disorders of sex development: insights from targeted gene sequencing of a large international patient cohort. Genome Biology, 17, 243.

Fan, W., Wang, B., He, S., Zhang, T., Yin, C., Chen, Y., . . Li, L. 2016. A Novel Missense Mutation 224G>T (R75M) in SRY Coding Region Interferes with Nuclear Import and Results in 46, XY Complete Gonadal Dysgenesis. PLoS One, 11, e0168484.

Fernandez, R., Marchal, J. A., Sanchez, A. \& Pasaro, E. 2002. A point mutation, R59G, within the HMG-SRY box in a female $45, \mathrm{X} / 46, \mathrm{X}$, psu dic(Y)(pter-->q11::q11-->pter). Hum Genet, 111, 242-6.

Filges, I., Kunz, C., Miny, P., Boesch, N., Szinnai, G., Wenzel, F., . . Heinimann, K. 2011. A novel missense mutation in the high mobility group domain of SRY drastically reduces its DNA-binding capacity and causes paternally transmitted 46,XY complete gonadal dysgenesis. Fertil Steril, 96, 851-5.

Forwood, J. K., Harley, V. \& Jans, D. A. 2001. The C-terminal nuclear localization signal of the sex-determining region $Y(S R Y)$ high mobility group domain mediates nuclear import through importin beta 1. J Biol Chem, 276, 46575-82.

Gimelli, G., Gimelli, S., Dimasi, N., Bocciardi, R., Di Battista, E., Pramparo, T. \& Zuffardi, O. 2007. Identification and molecular modelling of a novel familial mutation in the SRY gene implicated in the pure gonadal dysgenesis. Eur J Hum Genet, 15, 76-80.

Giuffrè, M., Sammarco, P., Fabiano, C., Giardina, F., Lunetta, F. \& Corsello, G. 2004. Identification of a new nonsense mutation (Tyr129Stop) of the SRY gene in a newborn infant with XY sex-reversal. Am J Med Genet A, 128a, 46-7.

Gonen, N., Quinn, A., O'neill, H. C., Koopman, P. \& Lovell-Badge, R. 2017. Normal Levels of Sox9 Expression in the Developing Mouse Testis Depend on the TES/TESCO Enhancer, but This Does Not Act Alone. PLoS Genet, 13, e1006520.

Haqq, C. M. \& Donahoe, P. K. 1998. Regulation of sexual dimorphism in mammals. Physiol Rev, 78, 1-33.

Harley, V. R., Layfield, S., Mitchell, C. L., Forwood, J. K., John, A. P., Briggs, L. J., . . Jans, D. A. 2003. Defective importin beta recognition and nuclear import of the sexdetermining factor SRY are associated with $X Y$ sex-reversing mutations. Proc Natl Acad Sci U S A, 100, 7045-50.

Hawkins, J. R., Taylor, A., Berta, P., Levilliers, J., Van Der Auwera, B. \& Goodfellow, P. N. 1992. Mutational analysis of SRY: nonsense and missense mutations in XY sex reversal. Hum Genet, 88, 471-4.

Helszer, Z., Dmochowska, A., Szemraj, J., Słowikowska-Hilczer, J., Wieczorek, M., Jędrzejczyk, S. \& Kałużewski, B. 2013. A novel mutation (c. 341A>G) in the SRY gene in a 46,XY female patient with gonadal dysgenesis. Gene, 526, 467-70. 
Hersmus, R., De Leeuw, B. H., Stoop, H., Bernard, P., Van Doorn, H. C., Brüggenwirth, H. T., . . Looijenga, L. H. 2009. A novel SRY missense mutation affecting nuclear import in a 46,XY female patient with bilateral gonadoblastoma. Eur J Hum Genet, $17,1642-9$.

Hiort, O., Gramss, B. \& Klauber, G. T. 1995. True hermaphroditism with 46,XY karyotype and a point mutation in the $<\mathrm{em}>\mathrm{SRY}</ \mathrm{em}>$ gene. The Journal of Pediatrics, 126, 1022.

Horoszewicz, J. S., Leong, S. S., Kawinski, E., Karr, J. P., Rosenthal, H., Chu, T. M., . . Murphy, G. P. 1983. LNCaP model of human prostatic carcinoma. Cancer Res, 43, 1809-18.

lida, T., Nakahori, Y., Komaki, R., Mori, E., Hayashi, N., Tsutsumi, O., . . Nakagome, Y. 1994. A novel nonsense mutation in the HMG box of the SRY gene in a patient with XY sex reversal. Hum Mol Genet, 3, 1437-8.

Imai, A., Takagi, A. \& Tamaya, T. 1999. A novel sex-determining region on Y (SRY) missense mutation identified in a 46,XY female and also in the father. Endocr J, 46, 735-9.

Jäger, R. J., Harley, V. R., Pfeiffer, R. A., Goodfellow, P. N. \& Scherer, G. 1992. A familial mutation in the testis-determining gene SRY shared by both sexes. Hum Genet, 90, 350-5.

Jordan, B. K., Jain, M., Natarajan, S., Frasier, S. D. \& Vilain, E. 2002. Familial mutation in the testis-determining gene SRY shared by an $X Y$ female and her normal father. $J$ Clin Endocrinol Metab, 87, 3428-32.

Karczewski, K. J., Francioli, L. C., Tiao, G., Cummings, B. B., Alföldi, J., Wang, Q., . . Macarthur, D. G. 2020. The mutational constraint spectrum quantified from variation in 141,456 humans. Nature, 581, 434-443.

Kent, W. J. 2002. BLAT--the BLAST-like alignment tool. Genome Res, 12, 656-64.

Klee, P., Béna, F., Birraux, J., Dahoun, S., Dirlewanger, M., Girardin, C., . . Schwitzgebel, V. M. 2012. A novel SRY mutation leads to asymmetric SOX9 activation and is responsible for mixed 46,XY gonadal dysgenesis. Horm Res Paediatr, 78, 188-92.

Koopman, P., Gubbay, J., Vivian, N., Goodfellow, P. \& Lovell-Badge, R. 1991. Male development of chromosomally female mice transgenic for Sry. Nature, 351, 117-21.

Kurtz, S., Lucas-Hahn, A., Schlegelberger, B., Göhring, G., Niemann, H., Mettenleiter, T. C. \& Petersen, B. 2021. Knockout of the HMG domain of the porcine SRY gene causes sex reversal in gene-edited pigs. Proceedings of the National Academy of Sciences, 118, e2008743118. 
Li, B., Zhang, W., Chan, G., Jancso-Radek, A., Liu, S. \& Weiss, M. A. 2001. Human sex reversal due to impaired nuclear localization of SRY. A clinical correlation. J Biol Chem, 276, 46480-4.

Li, M. A., Pettitt, S. J., Yusa, K. \& Bradley, A. 2010. Chapter Twelve - Genome-Wide Forward Genetic Screens in Mouse ES Cells. In: WASSARMAN, P. M. \& SORIANO, P. M. (eds.) Methods in Enzymology. Academic Press.

Liao, X., Liang, D., Li, Y., Xi, H., Quan, Y. \& Wu, L. 2011. Mutation analysis of the SRY, NR5A1, and DHH genes in six Chinese 46,XY women. J Matern Fetal Neonatal Med, 24, 863-6.

Lundberg, Y., Ritzén, M., Harlin, J. \& Wedell, A. 1998. Novel missense mutation (P131R) in the HMG box of SRY in XY sex reversal. Human Mutation, 11, S328-S329.

Mccann-Crosby, B., Mansouri, R., Dietrich, J. E., Mccullough, L. B., Sutton, V. R., Austin, E. G., ... Macias, C. G. 2014. State of the art review in gonadal dysgenesis: challenges in diagnosis and management. Int J Pediatr Endocrinol, 2014, 4.

Mcelreavey, K. D., Vilain, E., Boucekkine, C., Vidaud, M., Jaubert, F., Richaud, F. \& Fellous, M. 1992. XY sex reversal associated with a nonsense mutation in SRY. Genomics, 13, 838-40.

Mcelreavy, K., Vilain, E., Abbas, N., Costa, J. M., Souleyreau, N., Kucheria, K., . . Et Al. 1992. XY sex reversal associated with a deletion 5 ' to the SRY "HMG box" in the testis-determining region. Proc Natl Acad Sci U S A, 89, 11016-20.

Mitchell, C. L. \& Harley, V. R. 2002. Biochemical defects in eight SRY missense mutations causing XY gonadal dysgenesis. Mol Genet Metab, 77, 217-25.

Müller, J., Schwartz, M. \& Skakkebaek, N. E. 1992. Analysis of the sex-determining region of the $Y$ chromosome (SRY) in sex reversed patients: point-mutation in SRY causing sex-reversion in a 46,XY female. J Clin Endocrinol Metab, 75, 331-3.

Oh, H. J., Li, Y. \& Lau, Y. F. 2005. Sry associates with the heterochromatin protein 1 complex by interacting with a KRAB domain protein. Biol Reprod, 72, 407-15.

Okuhara, K., Tajima, T., Nakae, J. \& Fujieda, K. 2000. A novel missense mutation in the HMG box region of the SRY gene in a Japanese patient with an $X Y$ sex reversal. $J$ Hum Genet, 45, 112-4.

Özen, S., Onay, H., Atik, T., Solmaz, A. E., Özkınay, F., Gökşen, D. \& Darcan, Ş. 2017. Rapid Molecular Genetic Diagnosis with Next-Generation Sequencing in 46,XY Disorders of Sex Development Cases: Efficiency and Cost Assessment. Horm Res Paediatr, 87, 81-87.

Paliwal, P., Sharma, A., Birla, S., Kriplani, A., Khadgawat, R. \& Sharma, A. 2011. Identification of novel SRY mutations and SF1 (NR5A1) changes in patients with pure gonadal dysgenesis and 46,XY karyotype. Mol Hum Reprod, 17, 372-8. 
Paris, F., Philibert, P., Lumbroso, S., Baldet, P., Charvet, J. P., Galifer, R. B. \& Sultan, C. 2007. Primary amenorrhea in a $46, X Y$ adolescent girl with partial gonadal dysgenesis: identification of a new SRY gene mutation. Fertil Steril, 88, 1437.e21-5.

Pelletier, J., Schalling, M., Buckler, A. J., Rogers, A., Haber, D. A. \& Housman, D. 1991. Expression of the Wilms' tumor gene WT1 in the murine urogenital system. Genes Dev, 5, 1345-56.

Peng, H., Ivanov, A. V., Oh, H. J., Lau, Y. F. \& Rauscher, F. J., 3rd 2009. Epigenetic gene silencing by the SRY protein is mediated by a KRAB-O protein that recruits the KAP1 co-repressor machinery. J Biol Chem, 284, 35670-80.

Philibert, P., Leprieur, E., Zenaty, D., Thibaud, E., Polak, M., Frances, A. M., . . Sultan, C. 2010. Steroidogenic factor-1 (SF-1) gene mutation as a frequent cause of primary amenorrhea in 46,XY female adolescents with low testosterone concentration. Reprod Biol Endocrinol, 8, 28.

Phillips, N. B., Nikolskaya, T., Jancso-Radek, A., Ittah, V., Jiang, F., Singh, R., . . Weiss, M. A. 2004. Sry-directed sex reversal in transgenic mice is robust with respect to enhanced DNA bending: comparison of human and murine HMG boxes. Biochemistry, 43, 7066-81.

Phillips, N. B., Racca, J., Chen, Y. S., Singh, R., Jancso-Radek, A., Radek, J. T., . . Weiss, M. A. 2011. Mammalian testis-determining factor SRY and the enigma of inherited human sex reversal: frustrated induced fit in a bent protein-DNA complex. J Biol Chem, 286, 36787-807.

Plaseska-Karanfilska, D., Noveski, P., Kuzevska, K., Basheska, N., Kocova, M. \& Efremov, G. D. 2007. A new familial mutation (R133G) in the SRY gene. Clin Genet, 71, 480-2.

Poulat, F., Girard, F., Chevron, M. P., Gozé, C., Rebillard, X., Calas, B., . . Berta, P. 1995. Nuclear localization of the testis determining gene product SRY. J Cell Biol, 128, 737-48.

Poulat, F., Soullier, S., Gozé, C., Heitz, F., Calas, B. \& Berta, P. 1994. Description and functional implications of a novel mutation in the sex-determining gene SRY. Hum Mutat, 3, 200-4.

Racca, J. D., Chen, Y. S., Yang, Y., Phillips, N. B. \& Weiss, M. A. 2016. Human Sex Determination at the Edge of Ambiguity: INHERITED XY SEX REVERSAL DUE TO ENHANCED UBIQUITINATION AND PROTEASOMAL DEGRADATION OF A MASTER TRANSCRIPTION FACTOR. J Biol Chem, 291, 22173-22195.

Sánchez-Moreno, I., Canto, P., Munguía, P., De León, M. B., Cisneros, B., Vilchis, F., ... Méndez, J. P. 2009. DNA binding activity studies and computational approach of mutant SRY in patients with $46, \mathrm{XY}$ complete pure gonadal dysgenesis. Mol Cell Endocrinol, 299, 212-8. 
Sánchez-Moreno, I., Coral-Vázquez, R., Méndez, J. P. \& Canto, P. 2008. Full-length SRY protein is essential for DNA binding. Mol Hum Reprod, 14, 325-30.

Scarpa, M. G., Grazia, M. D. \& Tornese, G. 2017. 46,XY ovotesticular disorders of sex development: A therapeutic challenge. Pediatr Rep, 9, 7085.

Schäffler, A., Barth, N., Winkler, K., Zietz, B., Rümmele, P., Knüchel, R., . . Palitzsch, K. D. 2000. Identification of a new missense mutation (Gly95Glu) in a highly conserved codon within the high-mobility group box of the sex-determining region $\mathrm{Y}$ gene: report on a 46,XY female with gonadal dysgenesis and yolk-sac tumor. $J$ Clin Endocrinol Metab, 85, 2287-92.

Scherer, G., Held, M., Erdel, M., Meschede, D., Horst, J., Lesniewicz, R. \& Midro, A. T. 1998. Three novel SRY mutations in XY gonadal dysgenesis and the enigma of $X Y$ gonadal dysgenesis cases without SRY mutations. Cytogenet Cell Genet, 80, 18892.

Schmitt-Ney, M., Thiele, H., Kaltwasser, P., Bardoni, B., Cisternino, M. \& Scherer, G. 1995. Two novel SRY missense mutations reducing DNA binding identified in XY females and their mosaic fathers. Am J Hum Genet, 56, 862-9.

Shahid, M., Dhillion, V. S., Jain, N., Hedau, S., Diwakar, S., Sachdeva, P., . . Husain, S. A. 2004. Two new novel point mutations localized upstream and downstream of the HMG box region of the SRY gene in three Indian 46,XY females with sex reversal and gonadal tumour formation. Mol Hum Reprod, 10, 521-6.

Shahid, M., Dhillon, V. S., Aslam, M. \& Husain, S. A. 2005. Three new novel point mutations localized within and downstream of high-mobility group-box region in SRY gene in three Indian females with Turner syndrome. J Clin Endocrinol Metab, 90, 2429-35.

Shahid, M., Dhillon, V. S., Hussain, Z., Masa, J. F., Aslam, M., Raish, M., . . Husain, S. A. 2008. Analysis of the SRY gene in two sex-reversed $X Y$ sisters identifies two new novel point mutations in the high mobility group box domain. Fertil Steril, 90, 1199.e1-8.

Sim, H., Rimmer, K., Kelly, S., Ludbrook, L. M., Clayton, A. H. \& Harley, V. R. 2005. Defective calmodulin-mediated nuclear transport of the sex-determining region of the Y chromosome (SRY) in XY sex reversal. Mol Endocrinol, 19, 1884-92.

Stoppa-Vaucher, S., Ayabe, T., Paquette, J., Patey, N., Francoeur, D., Vuissoz, J. M., . . Deal, C. L. 2012. 46, XY gonadal dysgenesis: new SRY point mutation in two siblings with paternal germ line mosaicism. Clin Genet, 82, 505-13.

Südbeck, P. \& Scherer, G. 1997. Two independent nuclear localization signals are present in the DNA-binding high-mobility group domains of SRY and SOX9. J Biol Chem, 272, 27848-52. 
Tajima, T., Nakae, J., Shinohara, N. \& Fujieda, K. 1994. A novel mutation localized in the 3' non-HMG box region of the SRY gene in 46,XY gonadal dysgenesis. Hum Mol Genet, 3, 1187-9.

Veitia, R., Ion, A., Barbaux, S., Jobling, M. A., Souleyreau, N., Ennis, K., . . Mcelreavey, K. 1997. Mutations and sequence variants in the testis-determining region of the $Y$ chromosome in individuals with a 46,XY female phenotype. Hum Genet, 99, 648-52.

Wang, X., Xue, M., Zhao, M., He, F., Li, C. \& Li, X. 2018. Identification of a novel mutation (Ala66Thr) of SRY gene causes $X Y$ pure gonadal dysgenesis by affecting DNA binding activity and nuclear import. Gene, 651, 143-151.

Weiss, M. A., Ukiyama, E. \& King, C. Y. 1997. The SRY cantilever motif discriminates between sequence- and structure-specific DNA recognition: alanine mutagenesis of an HMG box. J Biomol Struct Dyn, 15, 177-84.

Whitfield, L. S., Lovell-Badge, R. \& Goodfellow, P. N. 1993. Rapid sequence evolution of the mammalian sex-determining gene SRY. Nature, 364, 713-5.

Xu, K., Su, N., Zhang, H., Zhu, J. \& Cheng, X. 2020. A case report of 46,XY partial gonadal dysgenesis caused by a novel mutation in the sex-determining region gene. Trans/ Pediatr, 9, 867-872.

Xue, M., Wang, X., Li, C., Zhao, M., He, F. \& Li, X. 2019. Novel pathogenic mutations in disorders of sex development associated genes cause $46, X Y$ complete gonadal dysgenesis. Gene, 718, 144072.

Zeng, Y. T., Ren, Z. R., Zhang, M. L., Huang, Y., Zeng, F. Y. \& Huang, S. Z. 1993. A new de novo mutation (A113T) in HMG box of the SRY gene leads to XY gonadal dysgenesis. J Med Genet, 30, 655-7.

Zenteno, J. C., Carranza-Lira, S., Jiménez, A. L. \& Kofman, S. 2003. A de novo phe671eu mutation in the SRY gene in a patient with complete $46, X Y$ gonadal dysgenesis. $J$ Endocrinol Invest, 26, 1117-9.

Zhao, L., Ng, E. T., Davidson, T. L., Longmuss, E., Urschitz, J., Elston, M., . . Koopman, P. 2014a. Structure-function analysis of mouse Sry reveals dual essential roles of the Cterminal polyglutamine tract in sex determination. Proc Natl Acad Sci U S A, 111, 11768-73.

Zhao, L., Ng, E. T. \& Koopman, P. 2014b. A piggyBac transposon- and gateway-enhanced system for efficient BAC transgenesis. Developmental Dynamics, 243, 1086-1094.

Zhou, X., Smith, A. J., Waterhouse, A., Blin, G., Malaguti, M., Lin, C. Y., . . L Lowell, S. 2013. Hes 1 desynchronizes differentiation of pluripotent cells by modulating STAT3 activity. Stem Cells, 31, 1511-22. 